DOI: 10.17951/en.2019.4.263-275

\begin{tabular}{cc}
\hline & ANNALES \\
& UNIVERSITATIS MARIAE CURIE-SKŁODOWSKA \\
LOL. IV & SECTIO N \\
\hline
\end{tabular}

\author{
Barbara Myrdzik \\ Uniwersytet Marii Curie-Skłodowskiej w Lublinie \\ ORCID: https://orcid.org/0000-0001-6676-0166 \\ myrdzik@poczta.onet.pl
}

\title{
O kształtowaniu umiejętności wartościowania nie tylko w procesie edukacji polonistycznej
}

\author{
Forming the Ability of Value Assessment \\ Not Only in Polish Philology Education
}

\begin{abstract}
Streszczenie: W artykule podjęto zagadnienie kształtowania wartościowania w procesie wychowania i kształcenia. Podkreślono rolę empatii w wartościowaniu i ocenianiu oraz uwarunkowań, które sprzyjają jej rozwojowi. W przyjętym przez autorkę rozumieniu empatia tworzy proces emocjonalno-poznawczy, który odgrywa ogromną rolę w edukacji młodego człowieka. Przywołano koncepcję myślenia krytycznego Hannah Arendt, która zwróciła uwagę na to, że warunkiem myślenia jest samoświadomość - w jej przestrzeni dialogujemy nie tylko z innymi ludźmi, lecz również z samym sobą. W skład krytycznego myślenia wchodzi też umiejętna, jasna prezentacja własnego stanowiska. W niniejszym opracowaniu autorka podkreśliła rolę literatury i języka w kształtowaniu umiejętności wartościowania oraz odpowiedzialność polonisty, który otrzymuje do dyspozycji bogaty warsztat metodyczny, a także rolę gier i zabaw w kształtowaniu umiejętności wartościowania. Przygotowanie ucznia na spotkanie z wartościami i kształtowanie umiejętności wartościowania jest zaś postrzegane w szerszej perspektywie aksjologicznej, uwzględniającej wiek ucznia, jego możliwości rozwojowe, wpływ środowiska rodzinnego i edukacji.
\end{abstract}

Słowa kluczowe: wartościowanie; wychowanie; empatia; ocenianie; kompetencja emocjonalna; trening wyobraźni; dialog; myślenie krytyczne; perswazja narracyjna; wrażliwość; autonomia 
W wierszu Wszystko Wisława Szymborska napisała:

Wszystko -

Słowo bezczelne i nadęte pychą.

Powinno być pisane w cudzysłowie.

Udaje, że niczego nie pomija,

że skupia, obejmuje, zawiera i ma.

A tymczasem jest tylko

strzępkiem zawieruchy ${ }^{1}$.

Wszystko oceniamy i wartościujemy, choć słowo wszystko jest według poetki bezczelne, bo znaczeniowo zbyt ogólne wobec jednostkowości istnienia, różnorodności rzeczy i spraw tego świata. Najłatwiej to „wszystko” można zaobserwować na forach internetowych - internauci wartościują wszystkie zjawiska, do których się odnoszą w mediach społecznościowych. Dość powszechne jest stosowanie negatywnych określeń oceniających, a dyskusje toczące się wokół spornych tematów zwykle wzmacniają konflikt wokół sposobów ich nazywania. Nie ma w tym ocenianiu kontaktu face to face, nadawca jest odbiorcy nieznany, a odbiorca jest najczęściej wirtualny, więc przy wolności słowa komentować może każdy, wypisywać zarówno słowa podziwu, jak i hejtu.

Często w życiu społecznym obserwujemy wygłaszanie złośliwych lub wulgarnych uwag w stosunku do różnych osób, niszczenie przedmiotów, narzucanie własnych zasad czy poglądów innym, negatywne lub wrogie nastawienie do wszystkich i wszystkiego, co nie mieści się w horyzoncie myślenia danej osoby lub grupy. Panuje „wszystko”.

Alarmujące doniesienia z badań psychologicznych, z których wynika, że do szkół trafia coraz więcej dzieci ze znaczącym defektem w zakresie współodczuwania i empatii, zmuszają do zadania pytania, jakie błędy wychowawcze są tego przyczyną. W świetle diagnoz psychologicznych należy stwierdzić, że są to dzieci, które nie doświadczyły wystarczającego wczuwania się w ich sytuacje

1 W. Szymborska, Wszystko, [w:] eadem, Chwila, Kraków 2002, s. 45. 
i potrzeby, nie doznały czułości na odpowiednim etapie swojego rozwoju oraz w znacznym stopniu reagują na nowe lub inne sytuacje agresją ${ }^{2}$.

Marzena Żylińska, autorka książki Neurodydaktyka. Nauczanie i uczenie się przyjazne mózgowi, zauważa: „Mówienia uczymy się w dialogu, zachowań społecznych - we wzajemnych relacjach z innymi ludźmi. [...] Udowodniono już, że nastolatki cierpią na coraz poważniejszą utratę empatii - tym większą, im więcej czasu spędzają przed różnymi ekranami”’.

Czy i co może zmienić w tym zakresie kształcenie i wychowanie? Sądzę, że mają one duże znaczenie. Do najbardziej istotnych elementów wychowania należą, po pierwsze, właściwa edukacja aksjologiczna o charakterze procesualnym, otwartym, wiążącym się z empatią i różnymi sytuacjami sprzyjającymi doświadczeniu wartości, a nie z tresurą kulturowąa ${ }^{4}$, przyswajaniem gotowych, ugruntowanych $w$ tradycji ocen bez rozumienia istoty ich wartościowości. Po drugie, wiedza na temat wartości i rozwijanie w człowieku zdolności do ich rozpoznawania i hierarchizowania, rozwijanie empatii. Przyjęcie określonej teorii wartości, powiązane z wybraną antropologią, wpływa w sposób zasadniczy na program wychowawczy, cele i zadania edukacyjne, dobór treści przedmiotowych, a także - w pewnym stopniu - na dobór metod nauczania. Po trzecie, samo doświadczenie wartości, nie tylko uobecnionych w dziełach literackich i innych tekstach kultury, lecz również wyrażane w działaniach społecznych.

Wychowywać to znaczy dawać świadectwo tym wartościom, które człowiek w swoim życiu widzi, weryfikuje, jest im posłuszny. Wtedy ten, kto ma twarz, którą rzeźbi, może stanąć wobec młodego człowieka, którego twarz na wiele kształtów może być wyrzeźbiona. Nie jest wtedy rzemieślnikiem, który dłubie coś tam, który wpycha w gotowe formułki, ustawia według jakiegoś drobiazgowo rozumianego porządku, zasad wychowawczych, po prostu staje wobec człowieka twarzą w twarz ${ }^{5}$.

W powyższej wypowiedzi Jan A. Kłoczowski podkreśla rolę doświadczenia i dialogu oraz wzorca wychowawczego wolnego od natrętnego moralizowania,

2 S. Kozak, Patologia analfabetyzmu emocjonalnego. Przyczyny i skutki braku empatii w rodzinie i środowisku pracy, Warszawa 2012, s. 170.

3 M. Żylińska, Neurodydaktyka. Nauczanie i uczenie się przyjazne mózgowi, Toruń 2013, s. 170 .

4 Określenie Ewy Bieńkowskiej. Zob. W. Stróżewski, Wokót piękna. Szkice z estetyki, Kraków 2002, s. 362.

5 J.A. Kłoczowski, Co znaczy: wychowywać w zgodzie z własnym sumieniem, „W drodze” 1984, nr 7, s. 19. 
ale wiarygodnego moralnie, bo „sprawdzonego sobą". Nie tyle obiektywnie poznawana wartość stanowi podstawę do jej uznania, ile zgodność jej aktualizowania z całokształtem przekonań człowieka, poświadczonych przez postawy życiowe osób znaczących dla niego. Są to „Znaczący Inni”, którymi są rodzice, wychowawcy, wybrane autorytety, przekazy kultury itd. Oddziaływanie osoby znaczącej zostawia trwały, szczególny ślad w strukturach psychicznych oraz zachowaniu jednostki i ma fundamentalne znaczenie dla przebiegu rozwoju psychospołecznego, zarówno w dzieciństwie i adolescencji, jak i w dorosłości.

Następne, chociaż nie jako czwarte w kolejności, uwarunkowanie wychowania, lecz równorzędne z pierwszym, to dobra kondycja całego społeczeństwa, którego zachowania wpływają na jednostki i ich poczucie bezpieczeństwa bez lęku (podsycanego przez media, polityków itd.), który wywołuje sprzeciw wobec postaw tolerancyjnych.

Badania wskazują, jak ważna jest empatia w wartościowaniu i ocenianiu. Empatia nie jest wrodzona, lecz kształtowana w toku doświadczenia ${ }^{6}$. Zaczynem są podmiotowe uwarunkowania empatii, jednak obok zdolności biologicznych i różnic indywidualnych ważne jest doświadczenie przyswojenia przez dziecko wartości prospołecznych i zachowań empatycznych, jakie przekazują mu rodzice, a następnie szkoła.

Zdaniem Marka H. Davisa ${ }^{7}$ ważne jest też zaspokojenie potrzeb dziecka w atmosferze bezpieczeństwa, sprawiające, że jest ono w mniejszym stopniu skoncentrowane na trosce o siebie, a przez to jest bardziej wrażliwe na potrzeby innych. Empatia wymaga również umiejętności przyjmowania perspektywy drugiej osoby, wstrzymywania się od ocen, rozpoznawania i komunikowania emocji - to feeling with peoples. Współwystępuje z tendencją do konstruktywnego rozwiązywania konfliktów oraz z poczuciem odpowiedzialności za siebie i innych.

Empatia jest powszechnie uznawana za podstawowy mechanizm interakcji w komunikacji człowieka ${ }^{8}$. Kształtuje postawę oznaczającą autentyczną otwartość i szacunek wobec innych ludzi oraz dążenie do zrozumienia cudzych doświadczeń9. Pozwala nie tylko trafnie interpretować akty komunikacji, osobowość i zachowanie innych osób, ale i to zachowanie przewidzieć. Pokonywanie komunikacyjnych barier i pozbywanie się stereotypowego myślenia ma pozytywny związek z przestrzeganiem zasad moralnych i ich rozumieniem. Empatia jest jednym

\footnotetext{
J. Bauer, Empatia. Co potrafia lustrzane neurony, Warszawa 2008, s. 69-70.

M.H. Davis, Empatia. O umiejętności współodczuwania, Gdańsk 1999.

J. Rembowski, Empatia, Warszawa 1989.

9 Z. Uchnast, Empatia jako postawa egzystencjalna, „Roczniki Filozoficzne” 1996, nr 4, s. 37 52; idem, Empatia osobowa: metoda pomiaru, „Przegląd Psychologiczny” 2001, nr 2, s. 189-207.
} 
z ważniejszych czynników determinujących rozwój osobowości, gdyż wyrasta z samoświadomości: im bardziej jesteśmy otwarci na nasze własne emocje, tym sprawniej odczytujemy uczucia innych osób ${ }^{10}$.

Według badań Davida R. Steinmanna i Davida B. Sawina ${ }^{11}$ dzięki empatii zmniejszają się agresja i przemoc, a zwiększa się stopień altruizmu. Hannah Arendt zwróciła uwagę na to, że „banalność zła” ${ }^{12}$ ujawnia się w sytuacjach codziennych, kiedy osoby niewykazujące wcześniej żadnych zaburzeń zachowują się okrutnie w stosunku do innych ludzi lub całych grup społecznych, gdyż zawiodło myślenie i uwzględnianie sytuacji innego człowieka.

Podsumowując te krótkie ustalenia, trzeba powiedzieć, że w literaturze psychologicznej empatia bywa definiowana na dwa sposoby:

- jako emocjonalna reakcja na emocje innej osoby (emotional empathy), czyli współodczuwanie tych emocji i umiejętność dzielenia się własnymi emocjami z drugą osobą; czasowa identyfikacja ze stanem drugiej osoby bez utraty własnej tożsamości i naruszania ustanowionych przez siebie granic,

- jako proces poznawczy (cognitive empathy), czyli umiejętność przyjmowania ról i perspektyw innych osób ${ }^{13}$.

W przyjętym przeze mnie rozumieniu empatii oba znaczenia tego pojęcia wzajemnie się uzupełniają, tworząc proces emocjonalno-poznawczy, który odgrywa ogromną rolę w edukacji.

Empatię można i należy kształtować w procesie wychowania, kształtowaniu wrażliwości w rodzinie, a także w szkole, np. stosując różne metody (np. odgrywanie ról społecznych, drama, gry wyobrażeniowe i inne) ${ }^{14}$. Uzyskaną tą drogą postawę Daniel Goleman nazwał kompetencją emocjonalną, której składnikami są: samoświadomość, samoregulacja, motywacja, umiejętności społeczne, empatia $^{15}$. Ponadto empatia to istotna, wręcz niezbędna, cecha każdego pedagoga, ale też podstawa procesów wartościowania.

10 D. Goleman, Inteligencja emocjonalna, Poznań 2007, s. 159.

11 D.R. Steinmann, D.B. Sawin, Moderators of Boys Aggressive Relations to Violence: Empathy and Interest, New York 1979.

12 H. Arendt, Eichmann w Jerozolimie. Rzecz o banalności zła, Kraków 2002.

13 M. Kliś, J. Kossewska, Rola empatii oraz innych cech osobowości w zapobieganiu objawom syndromu wypalenia zawodowego u nauczycieli, [w:] Rozwój człowieka i jego zagrożenia w świetle wspótczesnej psychologii, red. Z. Łoś, A. Oleszkiewicz, Wrocław-Lublin 1997, s. 223-232; S. Kozak, op. cit., s. 54.

14 D. Goleman, Inteligencja emocjonalna w praktyce, Poznań 1999.

15 Ibidem, s. 46. 
Zdolność do empatii wiąże się na poziomie ukształtowanych struktur psychicznych z preferowaniem określonych wartości, a przejawia się podobieństwem czy wręcz identycznością zachowań. Indywidualne różnice związane ze skłonnościami empatycznymi współwystępują z różnicami w preferencjach wartości. Emocje są zatem pierwotne w procesie społecznego uczenia się wartości oraz kształtowania postaw moralnych. Zinternalizowane wartości, wspomagane przez uczucie empatii, przyczyniają się do ograniczenia egoistycznych działań i sprzyjają socjalizacji zachowañ ${ }^{16}$.

Aktywne uczestniczenie w świecie wartości wiąże się z wrażliwością na to, co się w nim zjawia i czego się doświadcza. Rodzi się ono na styku empatii i wiedzy. Nie obywa się bez tych dwóch wymiarów. Wrażliwość jest - używając określenia Michała P. Markowskiego - „treningiem wyobraźni” ${ }^{17}$, którego nie może zabraknąć w edukacji polonistycznej. Autor ten, powołując się na Theodora Adorno, stwierdził: „Najpierw jest wrażliwość, potem zaś przychodzi poznanie, które nie może się do wrażliwości nie odwołać. Kiedy natomiast wrażliwość zostaje wykluczona, poznanie nie ma się na czym oprzeć"18. Markowski nie przeciwstawia uczuć teorii, lecz jest zwolennikiem (za Friedrichem Nietzschem) „wyraźnych” uczuć, czyli poddanych refleksji. „Uczucia daje się kształtować i na tym właśnie - na formowaniu wrażliwości - powinno polegać wykształcenie"19.

Polonista korzystający na co dzień z różnych form narracji potrafi wykorzystać ich właściwości do odsłaniania prawdy o człowieku oraz uruchomić wiedzę porównawczą dla refleksji egzystencjalnej. Narracja porządkuje wiedzę o świecie społecznym, tj. o ludziach i relacjach, które ich łączą. Elementy narracyjne zawierają wiadomości dotyczące:

- bohaterów (aktorów) danej historii,

- ich wartości oraz intencji (wraz z planami realizacji),

- możliwych komplikacji, które czekają bohaterów,

- uwarunkowań i szans realizacji intencji i planów,

- wyników działań podjętych przez bohaterów.

Pojęcie wartościowania odnosi się do językowo wyrażonego związku wartościującego podmiotu do przedmiotu; wartościowanie - rozumiane jako

16 M. Czerniawska, Empatia a system wartości, „Przegląd Psychologiczny” 2002, nr 1, s. $7-18$.

17 M.P. Markowski, Polityka wrażliwości. Wprowadzenie do humanistyki, Kraków 2013, s. 219-227.

18 Ibidem, s. 178.

19 Ibidem. 
przypisywanie wartości - podkreśla związek między nimi. W sposób szczególny wartościowaniu podlega postępowanie ludzkie, które ocenia się jako akceptowalne albo nie, owocne albo nie, społecznie aprobowane albo nie. W obu przypadkach, a więc na poziomie moralności i poznania, odwołujemy się do standardów, do kryteriów angażowanych w wartościujące oceny, a także w implikacje takich ocen. Takie wartościowanie jest interpretacją doświadczenia; zawiera aspekt emocjonalny, poprzez który, w sposób utajony, przejawia się zespół motywów podstawowych oraz klimat, w jakim odbywa się wartościowanie. Doświadczenie człowieka jest formą aktywności zarówno w codziennych kontaktach z innymi ludźmi i rzeczami (w tym z dziełami sztuki), jak i w sferze refleksji nad tym, w jaki sposób wszystko istnieje dla mnie. Dlatego w procesie wartościowania postaci, zdarzeń, wartości przyjmujemy różne perspektywy - punkt, który w danym momencie dominuje, wywiera decydujący wpływ na interpretowanie zdarzeń. Domagają się one eksplikacji, doboru trafnego słowa, które nie jest ostateczne. Dobra komunikacja z drugim człowiekiem polega na:

- umiejętności uważnego słuchania rozmówcy,

- mówieniu językiem jego potrzeb,

- zauważaniu jego hierarchii wartości,

- kulturalnym komunikowaniu swoich wartości i potrzeb,

- prowadzeniu dyskusji z poszanowaniem prawa rozmówcy do kontrargumentów,

- umiejętnym zarządzaniu emocjami i stresem,

- znajomością technik argumentacji i ich umiejętnym stosowaniem.

Poprzez język uczymy kulturalnej komunikacji, która jest fundamentem relacji z innymi: prowadzenia rozmowy, udziału w dyskusji, wypowiedzi tematycznej itd. Ta umiejętność nie ogranicza się jednak do poprawnego używania języka ojczystego, zakłada bowiem zdolność rozumienia przekazu, który płynie do niego od nadawcy, w tym uważnego słuchania. Ważne jest nie tylko to, co mówimy, lecz także sposób, w jaki mówimy - tym bardziej jest to istotne, gdyż wyrażenia i zwroty, które są używane na oznaczenie postawy wobec kogoś lub czegoś, mogą być nie tylko pozytywne, ale i negatywne.

Oprócz już wspomnianych metod przygotowujących dzieci do wartościowania, ważną rolę spełniają zabawy, w tym zabawa wyobrażeniowa, która polega na „rozruszaniu” mechanizmów wyobraźni. Jej istotą jest tworzenie wymyślonej historii, której bohaterowie mogą pochodzić z filmów, książek i gier komputerowych lub z innego źródła inspiracji. Na przykład figurka metalowego żołnierzyka, Supermana czy innej postaci służy dzieciom do tworzenia historii o ratowaniu świata przez wyimaginowanego bohatera. Dziecko wciela się w określoną postać i odgrywa wyobrażone przez siebie role. 
Możliwość ćwiczenia się w nowych rolach i zdobywania kompetencji do przyszłego przyjmowania kolejnych zadań nie tylko pomaga dziecku przystosować się do rozmaitych okoliczności, ale też daje więcej szans na projektowanie pasjonującego życia. Ponadto służy ćwiczeniu w podejmowaniu decyzji i wyborów, które wymagają uruchomienia dialogu, zarówno interpersonalnego, jak i intrapersonalnego. Wszystko zależy od tego, w jakiej roli osoba występuje w danym wyobrażeniu: jest aktorem czy obserwatorem obecnym (lub nie) w werbalizacji wyobrażonych treści.

Kod werbalny jest również nazywany mową wewnętrzną, umysłowym językiem, a kod percepcyjny - wyobraźnią, umysłowymi obrazami. Pierwsze powstają na bazie spostrzeżeń lub wyobrażeń, drugie zaś na bazie sądów. Oba systemy pozostają w relacji referencyjnej: jedno słowo może wywoływać wiele obrazów, jeden obraz wywołuje wiele słów. Kodowanie informacji jednocześnie $\mathrm{w}$ kodzie obrazowym i wyobrażeniowym powoduje lepsze zapamiętywanie informacji i jej przechowywanie.

Jak pokazują badania Małgorzaty Puchalskiej-Wasyl, rozmowy z wyobrażonym interlokutorem pełnią wiele funkcji. Są to np.:

- wsparcie, czyli źródło nadziei, poczucia bezpieczeństwa, sensu życia,

- substytucja prawdziwego kontaktu, forma argumentacji,

- eksploracja, droga poszukiwania nowych doświadczeń, ucieczka od szarej rzeczywistości,

- więź, poczucie zrozumienia, doświadczenie łączności z kimś bliskim,

- samodoskonalenie, przestroga przed powtarzaniem błędów, karcenie siebie,

- sposób uzyskania nowego punktu widzenia, rady, dystansu do problemu,

- samosterowanie (czynnik motywujący), kryterium do oceny siebie ${ }^{20}$.

W dialogach wewnętrznych przyjmowanie wielu „Ja” często wiąże się z różnymi sposobami widzenia świata, $\mathrm{z}$ wieloma sposobami myślenia $\mathrm{w}$ obrębie jednego umysłu.

Trzeba jeszcze wspomnieć o grach paragrafowych, gamebookach, grach książkowych, fantasolo, paragrafówkach - te terminy są w zasadzie synonimami i oznaczają specyficzny typ książek stanowiących hybrydę dzieła literackiego i klasycznego RPG (role-playing game). Są to pozycje zbudowane z wielu akapitów (paragrafów), a kolejność ich lektury zależy od wyborów czytelnika wcielającego się w głównego bohatera historii. Podjęte przez niego decyzje mają wpływ zarówno

20 M. Puchalska-Wasyl, Nasze wewnętrzne dialogi. O dialogowości jako sposobie funkcjonowania człowieka, Toruń 2016; eadem, Wyobrażeni rozmówcy - typy i funkcje, „Przegląd Psychologiczny" 2005, nr 1. 
na kształt fabuły, jak i na jej zakończenie, mające z reguły przynajmniej kilka wariantów niemożliwych do odkrycia za jednym razem. Często w tego typu publikacjach odbiorca tworzy postać, ustala wartości charakteryzujących ją parametrów, a w trakcie rozgrywki - gdy np. bohater staje przed jakąś trudnością (walka, test sprawności fizycznej albo intelektualnej) - rzuca kością. Wynik tej próby decyduje o dalszym ciągu historii. Dzięki takim rozwiązaniom podczas jednorazowej lektury czytelnik może poznać wyłącznie część możliwości uwzględnionych przez autora w fabule. Jednocześnie od odbiorcy wymaga się aktywności - nie tylko biernie poznaje on historię, lecz także czynnie w niej uczestniczy, jest zaangażowany, a co za tym idzie posiada realny wpływ na ciąg wydarzeń21.

Marcel Proust zwrócił uwagę na rolę fikcji literackiej w odbiorze czytelniczym:

W rzeczywistości bowiem każdy czytelnik jest, kiedy czyta, czytelnikiem samego siebie - swoim własnym. Dzieło pisarza to tylko rodzaj instrumentu optycznego zaofiarowanego czytelnikowi, aby czytelnik mógł rozeznać się w tym, czego, gdyby nie książka, może nie odkryłby w sobie. Rozpoznanie w samym sobie przez czytelnika tego, co mówi książka, to dowód jej prawdy²2.

Prawda uobecnia się w fikcji poprzez metaforyzację. Literatura dzięki temu, dystansując się od tego, co realne, konieczne i faktualne, odkrywa świat w jego nieprzejrzystości, otwiera dostęp do tego, co niejednoznaczne, nieokreślone i tajemnicze. Narracja literacka wiąże się z wybraną konwencją oraz wpływa na akceptację dwustronnego układu, co oznacza przyjęcie proponowanej umowności zarówno przez tworzących dzieła, jak i przez czytelników, do których są adresowane. Jeśli narracja literacka jest akceptowana przez odbiorcę, to cechuje ją siła polegająca właśnie na jej powtarzalności, rozpoznawalności, ciągłości wpływającej na tworzenie rzeczywistości artystycznej.

W okresie rozwoju kultury nasyconej interaktywnością młody człowiek, słuchając audycji radiowych, oglądając telewizyjne serwisy informacyjne i filmy czy po prostu rozmawiając na forach internetowych z rówieśnikami, często styka

21 M. Segit, Co to jest RPG? Wprowadzenie dla poczatkujacych, https://polter.pl/rpg/Co-tojest-RPG-c298 [dostęp: 10.10.2019]; J. Szeja, Co to jest RPG?, www.gildia.com/teksty/jerzy_szeja/ cotojestrpg [dostęp: 10.10.2019]; K. Jaworski, „Wybór należy do Ciebie”. Gry paragrafowe - druga mtodość zapomnianej formy rozrywki, „Studia Filologiczne” 2015, nr 28.

22 M. Proust, W poszukiwaniu straconego czasu, t. 7: Czas odnaleziony, Warszawa 1992, s. 271. 
się z różnymi historiami, które mogą mieć na niego wpływ. Melanie C. Green i Timothy C. Brock określili te sytuacje mianem „perswazji narracyjnej”, którą odróżniają od „perswazji retorycznej”, czyli zmiany wywołanej komunikatami podawanymi w formie argumentów ${ }^{23}$.

W tej nowej sytuacji rola nauczyciela nie może polegać na moralizowaniu, lecz na pokazywaniu szkodliwości jednokierunkowego, uproszczonego modelu komunikacji oraz działania różnych form manipulacji, z którymi młody człowiek może mieć styczność w modelowaniu świata wartości i ich hierarchizowaniu. W makrostrukturach społecznych, jakimi są szkoła i rodzina, trwają głównie wzory pozytywne, sprzyjające ich istnieniu i rozwijaniu się społeczeństwa. Historia pokazuje jednak, że oddziaływanie wzoru może mieć charakter destruktywny, również dla danej społeczności (np. Hitler i Stalin, których kult zaczyna odżywać współcześnie).

Ważne jest wspieranie empatii i samodzielności myślenia. Są to procesy, które towarzyszą życiu, stanowią formę życia umysłu bazującą na wewnętrznym dialogu z samym sobą. Myślenie, poprzedzając wartościowanie, oczyszcza dla niego grunt, usuwając przeszkody w postaci przesądów, generalizacji czy obiegowych reguł. Dla określenia aktywności myślenia Sokrates używał metafory wiatru, który jako niewidoczny wicher myśli wietrzy nasze pojęcia i nawyki myślowe oraz powoduje, choć jest niewidoczny, że musimy je puścić w ruch ${ }^{24}$, a także metafory tkaniny Penelopy, prującej ściegi utkane wcześniej. Tak jest z myśleniem, szczególnie krytycznym, które usuwa poprzednie ustalenia dla nowych racji.

Młodzi w okresie dorastania wielką wagę przywiązują do prawdziwości i prawdy, rozumianej często jako manifestatio. Weryfikację prawdziwości spełnia krytyczne myślenie - każda poza i fałsz ze strony znaczących innych może prowadzić do kryzysu ich wiarygodności. Doświadczenie prawdziwości wpływa na umiejętność oceniania, rozwijania postawy krytycznej i selektywnej, która powoduje często niszczenie poprzednich ustaleń.

Przygotowanie ucznia na spotkanie z wartościami i kształtowanie umiejętności wartościowania dobrze jest postrzegać w szerszej perspektywie aksjologicznej, którą tworzą np. wiek ucznia, stopień jego dojrzałości intelektualnej, jego zaawansowanie edukacyjne i językowe, a także adaptacyjna rola wrażliwości, która ma zasadnicze znaczenie w radzeniu sobie z ciągle napływającymi

23 Narrative Impact: Social and Cognitive Foundations, eds. C. Green, J.J. Strange, T.C. Brock, Mahwah 2002; T.C. Brock, M.C. Green, Perswazja, Kraków 2007.

24 H. Arendt, Myślenie, Warszawa 2002, s. 374. 
informacjami i opiniami ${ }^{25}$. Wartościowanie wymaga wrażliwości i intensywności. Jak stwierdził Markowski:

Intensywność nie tkwi w pośpiechu czy pędzie. Jest raczej skupianiem, zgęszczaniem możliwości: możliwości życia, języka, wyobraźni, relacji z innymi ludźmi. Jest odkrywaniem w samym życiu innych wymiarów, innych pokładów znaczeń niż te, do których przywykliśmy. Jest przeciwko rutynie, przeciwko banalności, przeciwko życiu na łatwiznę, przeciwko wyświechtaniu myślenia. Nie wymaga wypadów pod biegun czy okrążania ziemi w czółnie z palmowych liści. Wystarczy jej kartka papieru, skrawek ekranu, parę minut, może godzin wolności ${ }^{26}$.

Jest ona zatem edukacją nastawioną na nauczanie myślenia i odczuwania, obszarem, w którym „decydujemy, czy dostatecznie kochamy świat, by przyjąć zań odpowiedzialność, a tym samym uchronić go przed zniszczeniem"27, ale też kształtowaniem tego, by pośród zgiełku współczesnego świata, wśród ludzi pochłoniętych często bezrefleksyjnym działaniem, nasi uczniowie potrafili zatrzymać się i pomyśleć, a dopiero potem wartościować ${ }^{28}$.

\section{BIBLIOGRAFIA}

Arendt H., Eichmann w Jerozolimie. Rzecz o banalności zła, Kraków 2002.

Arendt H., Kryzys edukacji, [w:] eadem, Między czasem minionym a przyszłym. Osiem ćwiczeń z myśli politycznej, Warszawa 1994.

Arendt H., Myślenie, Warszawa 2002.

Bauer J., Empatia. Co potrafia lustrzane neurony, Warszawa 2008.

Brock T.C., Green M.C., Perswazja, Kraków 2007.

Czerniawska M., Empatia a system wartości, „Przegląd Psychologiczny” 2002, nr 1.

Davis M.H., Empatia. O umiejętności współodczuwania, Gdańsk 1999.

Dąbrowski A., Wptyw emocji na poznawanie, „Przegląd Filozoficzny - Nowa Seria” 2012, nr 3.

Goleman D., Inteligencja emocjonalna, Poznań 2007.

Goleman D., Inteligencja emocjonalna w praktyce, Poznań 1999.

Hoffman M.L., The Contribution of Empathy to Justice and Moral Judgment, [w:] Empathy and Its Development, eds. N. Eisenberg, J. Strayer, Cambridge 1990.

25 A. Dąbrowski, Wptyw emocji na poznawanie, „Przegląd Filozoficzny - Nowa Seria” 2012, nr 3, s. 315-335.

26 M.P. Markowski, Sztuka intensywności, „Tygodnik Powszechny” 2016, nr 37 (dodatek „Conrad” 2016, nr 1).

27 H. Arendt, Kryzys edukacji, [w:] eadem, Między czasem minionym a przysztym. Osiem ćwiczeń z myśli politycznej, Warszawa 1994, s. 232.

28 Eadem, Myślenie, s. 240. 
Jaworski K., „Wybór należy do Ciebie”. Gry paragrafowe - druga młodość zapomnianej formy rozrywki, „Studia Filologiczne” 2015, nr 28.

Kliś M., Pojęcie empatii we wcześniejszych oraz wspótczesnych koncepcjach psychologicznych, „Psychologia Wychowawcza” 1998, nr 1.

Kliś M., Kossewska J., Rola empatii oraz innych cech osobowości w zapobieganiu objawom syndromu wypalenia zawodowego u nauczycieli, [w:] Rozwój człowieka i jego zagrożenia w świetle wspótczesnej psychologii, red. Z. Łoś, A. Oleszkiewicz, WrocławLublin 1997.

Kłoczowski J.A., Co znaczy: wychowywać w zgodzie z własnym sumieniem, „W drodze” 1984, nr 7.

Kozak S., Patologia analfabetyzmu emocjonalnego. Przyczyny i skutki braku empatii w rodzinie i środowisku pracy, Warszawa 2012.

Markowski M.P., Polityka wrażliwości. Wprowadzenie do humanistyki, Kraków 2013.

Markowski M.P., Sztuka intensywności, „Tygodnik Powszechny” 2016, nr 37 (dodatek "Conrad" 2016, nr 1).

Mikoś E., Empatia w hermeneutycznej interpretacji tekstu literackiego, „Polonistyka” 2008, $\mathrm{nr} 2$.

Narrative Impact: Social and Cognitive Foundations, eds. C. Green, J.J. Strange, T.C. Brock, Mahwah 2002.

Nussbaum M.C., Nie dla zysku. Dlaczego demokracja potrzebuje humanistów, Warszawa 2016.

Proust M., W poszukiwaniu straconego czasu, t. 7: Czas odnaleziony, Warszawa 1992.

Puchalska-Wasyl M., Nasze wewnętrzne dialogi. O dialogowości jako sposobie funkcjonowania człowieka, Toruń 2016.

Puchalska-Wasyl M., Wyobrażeni rozmówcy - typy ifunkcje, „Przegląd Psychologiczny” 2005, nr 1.

Rembowski J., Empatia, Warszawa 1989.

Segit M., Co to jest RPG? Wprowadzenie dla poczatkujacych, https://polter.pl/rpg/Coto-jest-RPG-c298 [dostęp: 10.10.2019].

Steinmann D.R., Sawin D.B., Moderators of Boys Aggressive Relations to Violence: Empathy and Interest, New York 1979.

Stróżewski W., O wielkości. Szkice z filozofii cztowieka, Kraków 2002.

Stróżewski W., Wokót piękna. Szkice z estetyki, Kraków 2002.

Szeja J., Co to jest RPG?, www.gildia.com/teksty/jerzy_szeja/cotojestrpg [dostęp: 10.10.2019].

Szymborska W., Wszystko, [w:] eadem, Chwila, Kraków 2002.

Uchnast Z., Empatia jako postawa egzystencjalna, „Roczniki Filozoficzne” 1996, nr 4.

Uchnast Z., Empatia osobowa: metoda pomiaru, „Przegląd Psychologiczny” 2001, nr 2.

Taylor Ch., Źródta podmiotowości. Narodziny tożsamości nowoczesnej, Warszawa 2001.

Tomczuk J., Dialogowy model empatii, [w:] Studia z psychologii w Katolickim Uniwersytecie Lubelskim, red. P. Francuz, P. Oleś, W. Otrębski, t. 12, Lublin 2005.

Trzebińska E., Empatia jako forma komunikacji interpersonalnej, „Przegląd Psychologiczny" 1985, nr 2.

Żylińska M., Neurodydaktyka. Nauczanie i uczenie się przyjazne mózgowi, Toruń 2013. 
Summary: In the article, the author addresses the issue of shaping valuation in the process of upbringing and education. It is emphasized the role of empathy in valuation and evaluation, as well as the conditions that contribute to its development. According to the author, empathy creates an emotional and cognitive process that plays a huge role in the education of a young person. She recalls the concept of critical thinking examined by Hannah Arendt, which draws attention to the fact that the condition of thinking is self-awareness, in its space we dialogue not only with other people, but also with ourselves. Critical thinking also includes a skilful, clear presentation of the author's own position. There has been paid attention to the role of literature and language in shaping valuation skills, the responsibility of a Polish philologist who has a rich methodological workshop at his disposal. The role of games and play in shaping valuation skills have been emphasized. The author perceives the student's preparation for meeting values and shaping valuation skills in a broader axiological perspective, taking into account the age of the student, his development opportunities, the impact of the family environment and education.

Keywords: evaluation; upbringing; empathy; assessment; emotional competence; imagination training; dialogue; critical thinking; narrative persuasion; sensitivity; autonomy 